\title{
NEW RECORDS OF LICHENICOLOUS FUNGI FROM SW POLAND
}

\author{
MARIA KOSSOWSKA \& KATARZYNA SZCZEPAŃSKA
}

\begin{abstract}
New localities of nine lichenicolous fungi from southwestern Poland are presented, of which Zwackhiomyces martinatianus (Arnold) Triebel \& Grube is reported as new for Poland and Chaenothecopsis viridireagens (Nádv.) A. F. W. Schmidt and Illosporium carneum Fr. as new for the Polish Sudetes. The first modern record of Karschia talcophila in Poland is given.
\end{abstract}

Key words: Ascomycota, biodiversity, lichens, Sudety Mts

Maria Kossowska, Department of Biodiversity and Plant Cover Protection, Faculty of Biological Sciences, University of Wroctaw, ul. Kanonia 6/8,50-328 Wroctaw,Poland; e-mail: kossmar@biol.uni.wroc.pl

Katarzyna Szczepańska, Department of Botany and Plant Ecology, Wroclaw University of Environmental and Life Sciences, pl. Grunwaldzki 24a,50-363 Wroctaw, Poland; e-mail: siemuszka@wp.pl

\section{INTRODUCTION}

The southwestern part of Poland, especially the Sudety Mountains and to a lesser degree Lower Silesia, is lichenologically one of the most intensely investigated regions of Poland, and to date $c a 1000$ lichen species have been recorded from there (Kossowska, unpublished). However, the occurrence and distribution of lichenicolous fungi there are still poorly recognized. Although distributional data from the region have been published in recent years (e.g., Kukwa 2004, 2005; Kukwa \& Czarnota 2006; Szczepańska 2007; Kossowska 2006, 2008; Kukwa \& Jabłońska 2008; Kukwa \& Flakus 2009; Kukwa et al. 2010), the details of the actual biodiversity of these fungi require further study.

During lichenological investigations conducted recently in the Sudetes, nine species of lichenicolous fungi were found, of which Zwackhiomyces martinatianus (Arnold) Triebel \& Grube is reported in Poland for the first time, and Chaenothecopsis viridireagens (Nádv.) A. F. W. Schmidt and Illosporium carneum Fr. are new for the Polish Sudetes.

\section{MATERIAL AND METHODS}

Specimens were identified using standard microscopic techniques and the following literature: Hawksworth
(1983), Triebel (1989), Smith et al. (2009), Groner (2006) and Czyżewska and Kukwa (2009). Anatomical characters were measured from hand-cut sections using a Nikon Eclipse E600 light microscope. Brief descriptions of the species are based on personal observations and measurements, along with data from the cited literature.

The collected material is housed in the private herbaria of the authors. The examined localities are given in the ATPOL grid square system (Cieśliński \& Fałtynowicz 1993).

\section{THE SPECIES}

\section{Abrothallus caerulescens Kotte}

Host: Xanthoparmelia conspersa (Ach.) Halle (thallus).

Ascomata apothecia, black, strongly convex, without excipulum. Ascospores brown, verrucose, 1-septate, relatively large $(10-17 \times 4-7 \mu \mathrm{m})$. The characteristic feature of the species is the mycelium which becomes bluish with Lugol's reagent. This is a commensalistic fungus growing exclusively on thalli of yellow-green species of Xanthoparmelia (Diederich 2003; Czyżewska \& Kukwa 2009).

Abrothallus caerulescens is rare in Poland, reported from only a few localities (Czyżewska 
\& Kukwa 2009). The record from the Przedgórze Sudeckie foreland presented below was noted by Fałtynowicz (2003), but without locality details, which are provided here.

Specimen eXamined. [Eb-76] PrZedgórze SuDECKIE FORELAND, Masyw Ślęży massif, Radunia Mt., on X. conspersa growing on serpentinite rock, 1999, M. Kossowska (hb. Kossowska 527).

\section{Arthrorhaphis aeruginosa R. Sant. \& Tønsberg}

Host: Cladonia sp. (squamules).

Ascomata sessile to sub-stipitate, black. Ascospores hyaline, acicular, 12-28 septate, 80-110 $\times 3-4 \mu \mathrm{m}$. The lichen thalli infected by this fungus turns aeruginose. The fungus parasitizes the squamules of various Cladonia species growing mainly in humid conditions (Santesson \& Tønsberg 1994; Czarnota \& Kukwa 2004).

Arthrorhaphis aeruginosa is common in Poland (Czyżewska \& Kukwa 2009; Kukwa et al. 2010), but in the Polish part of the Sudetes it was known from only one locality (Dimos-Zych \& Czarnota 2007). Now two additional localities are provided. Both specimens examined were sterile but easy to recognize by their characteristic aeruginose spots on infected basal squamules of the host.

SPeCimens EXAMINED. [Eb-80] WeSTERn SudETy MTS, Karpacz town - Granitowa Street, 640 m, on squamules of Cladonia sp. growing on the base of Acer pseudoplatanus, 2010, A. Juźwin \& M. Kossowska (hb. Kossowska 1249); KARKONOSZE MTS, Dolina Maliny valley, ca $750 \mathrm{~m}$, on squamules of Cladonia sp. growing on the base of Picea abies, 2011, P. Baryś \& M. Kossowska (hb. Kossowska 1282).

Chaenothecopsis viridireagens (Nádv.) A. F. W. Schmidt

Host: Chaenotheca stemonea (Ach.) Müll. Arg. (thallus).

Apothecia stalked, simple or branched, with obovoid capitulum. Spores 1-septate, brown, 5-7 $\times 2-3 \mu \mathrm{m}$, with weakly pigmented septum. The characteristic feature is the presence of reddish, $\mathrm{K}+$ persistently green, pigment in the capitulum and stalk of apothecia (Schmidt 1970). The species usually grows on the thalli of Chaenotheca species with Stichococcus as the photobiont or on free-living Stichococcus colonies (Groner 2006).

Chaenothecopsis viridireagens has been noted from a few localities in Poland as a lignicolous (Fałtynowicz 2003) and a lichenicolous species (Kukwa et al. 2010). The first record of the species from the Sudetes was parasitizing Chaenotheca stemonea.

SPECIMEN EXAMINED. [Ea-89] WESTERN SUDETY MTs, Karkonosze Mts, north slope of Kopa Mt., monitoring plot no. 192/20, $1125 \mathrm{~m}$, on Ch. stemonea growing on Picea abies, 2011, P. Jarema \& H. Fattynowicz (hb. Kossowska 1283).

\section{Clypeococcum hypocenomycis D. Hawksw.}

Host: Hypocenomyce scalaris (Ach.) Choisy (thallus).

Perithecia globose, immersed, arising in groups aggregated by a dark clypeus of the hyphae of host and invading fungus. Hamathecium formed by branched and anastamosing pseudoparaphyses. Ascospores brown, 1-septate, 11-14 × 5-6 $\mu \mathrm{m}$. The infected squamules of the host soon become black and waste away (Hawksworth 1980).

Clypeococcum hypocenomycis is very common in Poland (Czyżewska \& Kukwa 2009; Kukwa \& Flakus 2009; Kukwa et al. 2010), and known from the Sudetes (Kukwa \& Jabłońska 2008), with the following additional localities.

SPECIMENS EXAMINED. [Eb-80] WESTERN SUDETY MTs, Karkonosze Mts, Dolina Maliny valley, c. 700 m, on H. scalaris growing on rotten stump of Picea abies, 2011, P. Baryś \& M. Kossowska (hb. Kossowska 1260). [Eb-91] Central Sudety Mts, Góry Krucze Mts, Krucza Skała Mt., $650 \mathrm{~m}$, on H. scalaris growing on Pinus sylvestris, 17 Sept. 2011, K. Szczepańska (hb. Szczepańska 912).

\section{Illosporium carneum Fr.}

Host: Peltigera didactyla (With.) J. R. Laundon (thallus).

Conidial stage of fungus Pronectria robergei (Mont. \& Desm.) Lowen. Conidiophores forming pale pink, 200-300 $\mu \mathrm{m}$ wide sporodochia. Conidia simple, 6-7 $\mu \mathrm{m}$ diam., adhering in compact masses. The fungus is restricted to the thalli of Peltigera spp. (Hawksworth 1979). 
Illosporium carneum, a common species in Poland (Czyżewska \& Kukwa 2009; Kukwa \& Flakus 2009; Kukwa et al. 2010), is here recorded as new to the Polish Sudetes.

SPECIMEN EXAMINED. [Ea-78] Western Sudety Mts, Karkonosze Mts, Szrenica Mt., $1300 \mathrm{~m}$, on P. didactyla growing on soil, 5 Sept. 2010, A. Szczepański (hb. Szczepańska 866).

\section{Karschia talcophila (Flot.) Körb.}

Host: Diploschistes scruposus (Shreb.) Norman (thallus).

Apothecia black, rough, with persistant margins, $0.3-0.6 \mathrm{~mm}$ diam. Hamathecium of branched and anastomosing parapysoids. Ascospores brown, 1-septate, 11-17 × 6-8 $\mu \mathrm{m}$ (Hafellner 2004).

To date Karschia talcophila has been reported only by Stein (1879) from the region of Silesia, as "not rare" but without detailed localities. Its presence in Poland has now been confirmed; probably it is more frequent as it is easily overlooked.

SPECIMEN EXAMINED. [Eb-91] CENTRAL SUDETY MTs, Góry Krucze Mts, Krucza Skała Mt., 600 m, on D. scruposus growing on volcanic rock, 17 Sept. 2011, K. Szczepańska (hb. Szczepańska 915).

\section{Muellerella pygmaea (Körb.) D. Hawksw. s.str.}

Hosts: Rhizocarpon reductum Th. Fr. and Lecidea fuscoatra (L.) Ach. (thalli).

Perithecia globose, 175-250 $\mu \mathrm{m}$ diam., black, sessile or immersed in host thallus. Asci of 20-32 spores. Ascospores brown, 1-septate, 8-10 $\times$ 4-5 $\mu \mathrm{m}$, with relatively thick walls, finely ornamented (Triebel 1989).

Muellerella pygmaea is common on various species of epilithic crustose lichens in Poland (Czyżewska \& Kukwa 2009), and in the Sudetes it is known from several localities (Körber 1855; Stein 1879; Kukwa \& Czarnota 2006; Szczepańska 2008; Kukwa \& Flakus 2009).

SPECIMENS EXAMINED. [Eb-40] WeSTERN SUDETY MTS, Pogórze Kaczawskie foothills, Ostrzyca Mt., $501 \mathrm{~m}$, on $R h$. reductum growing on basalt rock, 26 Sept. 2012, K. Szczepańska (hb. Szczepańska 930); same locality, on L. fuscoatra growing on basalt rock,
26 Sept. 2012, M. Kossowska (hb. Kossowska 1278). [Eb-91] Central Sudety MTs, Góry Krucze Mts, Krucza Skała Mt., $600 \mathrm{~m}$, on Rh. reductum growing on volcanic rock, 17 Sept. 2011, K. Szczepańska (hb. Szczepańska 921).

Stigmidium fuscatae (Arnold) R. Sant.

Host: Acarospora fuscata (Nyl.) Arnold (thallus).

Ascomata perithecioid, globose, brown in upper part and hyaline in lower part, immersed or semi-immersed in host squamules. Hamathecium of pseudoparaphyses. Ascospores hyaline, 1-septate, $10-12 \times 4-5 \mu \mathrm{m}$, with slightly narrower lower cell (Triebel \& Cáceres 2004).

Stigmidium fuscatae is a rare species in Poland, formerly known from only six localities (Kukwa et al. 2010); in the Sudety Mts it has been recorded twice (Kukwa \& Jabłońska 2008; Kukwa et al. 2010).

Specimens eXAmined. [Eb-64] PrZedgórze SudECKIE FORELAND, Wzgórza Strzegomskie hills, Krzyżowa Mt., ca $350 \mathrm{~m}$, on A. fuscata growing on basalt rock, 19 May 2013. K. Szczepańska (hb. Szczepańska 950). [Eb-91] Central Sudety MTs, Góry Krucze Mts, Krucza Skała Mt., $600 \mathrm{~m}$, on A. fuscata growing on volcanic rock, 17 Sept. 2011, K. Szczepańska (hb. Szczepańska 909).

Zwackhiomyces martinatianus (Arnold) Triebel \& Grube

Host: Porpidia sp. (thallus).

Ascomata perithecioid, globose to pyriform, 90-130 $\mu \mathrm{m}$ diam., immersed in host thallus. Interascal filaments present, branching and anastomosing. Ascospores relatively small, $11-17 \times 3-5 \mu \mathrm{m}$, hyaline, 1-septate. The fungus may induce gall formation on infected thalli (Grube \& Hafellner 1990; Calatayud et al. 2007).

Zwackhiomyces martinatianus is a rare lichenicolous fungus, confined to Porpidia species. It is known from central and western parts of Europe, having been found in Austria, Belgium, France, Germany, Iceland, Italy, Luxembourg and Spain (Grube \& Hafellner 1990; Sérusiaux et al. 1999; Ertz et al. 2008; Brackel 2010). Here it is reported as new for Poland. The examined specimen 
corresponds with the description, but the infection did not cause the development of distinct galls on the host.

Specimen eXAmined. [Eb-91] Central Sudety Mts, Góry Krucze Mts, Krucza Skała Mt., 600 m, on Porpidia sp. growing on volcanic rock, 17 Sept. 2011, K. Szczepańska (hb. Szczepańska 944).

ACKNOWLEDGEMENTS. We are grateful to Dr. Martin Kukwa (Gdańsk, Poland) for confirming the identification of Abrothallus caerulescens and for valuable information and comments, to Dr. Adam Flakus for helpful remarks on the manuscript, and to Professor Mark Seaward (Bradford, UK) for improving the English.

\section{REFERENCES}

BRACKEL W. VON 2010. Some lichenicolous fungi and lichens from Iceland, including Lichenopeltella uncialicola sp. nov. Herzogia 23: 93-109.

CAlatayud V., Triebel D. \& PÉREZ-OrTEGa S. 2007. Zwackhiomyces cervinae, a new lichenicolous fungus (Xanthopyreniaceae) on Acarospora, with a key to the known species of the genus. Lichenologist 39: 129-134.

CieŚLiŃSKI S. \& FAŁTYNOWICZ W. (eds) 1993. Atlas of the geographical distribution of lichens in Poland. Part I. W. Szafer Institute of Botany, Polish Academy of Sciences, Kraków.

Czarnota P. \& KuKwa M. 2004. Some sorediate lichens and lichenicolous fungi new to Poland. Graphis Scripta 15: 24-32.

CZYŻEWSKA K. \& KUKWA M. 2009. Lichenicolous fungi of Poland. A catalogue and key to species. W. Szafer Institute of Botany, Polish Academy of Sciences, Kraków.

DIEDERICH P. 2003. New species and new records of American lichenicolous fungi. Herzogia 16: 41-90.

Dimos-Zych M. \& CZARnota P. 2007. Lichens of the Dolina Łomniczki valley and the Kocioł Łomniczki cirque in the eastern part of the Giant Mountains (Polish Sudetes). In: J. ŠTURSA \& R. KNAPIK (eds), Geoecological Problems of the Gaint Mountains. Proceedeings of the International Conference, October 2006, Svoboda n. Úpou. Opera Corcontica 44: 289-204 (in Polish with English summary).

Ertz D., Diederich P., Brand A. M., van Den Boom P. \& SÉRUSIAUX E. 2008. New or interesting lichens and lichenicolous fungi from Belgium, Luxembourg and northern France. XI. Bull. Soc. Nat. luxemb. 109: 35-51.

FAŁTYNOWICZ W. 2003. The lichens, lichenicolous and allied fungi of Poland. An annotated checklist. W. Szafer Institute of Botany, Polish Academy of Sciences, Kraków.
Groner U. 2006. The genus Chaenothecopsis (Mycocaliciaceae) in Switzerland, and a key to the European species. Lichenologist 38: 395-406.

GRUBE M. \& HAFELLNER J. 1990. Studien an flechtenbewohnenden pilzen der sammelgattung Didymella (Ascomycetes, Dothideales). Nova Hedwigia 51: 283-360.

HAFELLNER J. 2004. Karschia. In: T. H. NASH III, B. D. RYAN, C. GRIES \& F. BUGARTZ (eds), Lichen flora of the Greater Sonoran Desert Region. 2: 655. Lichens Unlimited, Arizona State University, Tempe.

HAWKSWORTH D. L. 1979. The lichenicolous Hyphomycetes. Bull. Brit. Mus. (Nat. Hist.), Bot. 6: 183-300.

HAWKSWORTH D. L. 1980. Notes on British lichenicolous fungi III. Notes Roy. Bot. Gard. Edinburgh 38: 165-183.

HAWKSWORTH D. L. 1983. A key to the lichen-forming, parasitic, parasymbiotic and saprophytic fungi occuring on lichens in the British Isles. Lichenologist 15: 1-44.

KÖRBER G. 1855. Systema lichenum Germaniae. Die Flechten Deutschlands (insbesondere Schlesiens). Trevendt \& Granier, Breslau.

KossowsKa M. 2006. Checklist of lichens and allied fungi of the Polish Karkonosze Mts. W. Szafer Institute of Botany, Polish Academy of Sciences, Kraków.

KOSSOWSKA M. 2008. New and interesting lichenicolous fungi of the Karkonosze Mountains, SW Poland. Herzogia 21: 229-232.

KUKWA M. 2004. New or interesting records of lichenicolous fungi from Poland II. Herzogia 17: 67-75.

KUKWA M. 2005. New or interesting records of lichenicolous fungi from Poland III. Herzogia 18: 37-46.

KuKWA M. \& CZARNOTA P. 2006. New or interesting records of lichenicolous fungi from Poland IV. Herzogia 19: 111-123.

KUKWA M. \& FLAKUS A. 2009. New or interesting records of lichenicolous fungi from Poland VII. Species mainly from Tatra Mountains. Herzogia 22: 191-211.

KUKWA M. \& JABŁOŃSKA A. 2008. New or interesting records of lichenicolous fungi from Poland VI. Herzogia 21: 167-179.

Kukwa M., Czarnota P. \& Perz P. 2010. New or interesting records of lichenicolous fungi from Poland VIII. Herzogia 23: $111-119$.

SANTESSON R. \& TøNSBERG T. 1994. Arthrorhaphis aeruginosa and A. olivaceae, two new lichenicolous fungi. Lichenologist 26: 295-299.

SCHMIDT A. 1970. Anatomisch-taxonomische Unterschungen an europäischen Arten der Familie Caliciaceae. Mitt. Staatsinst. Allg. Bot. Hamburg 13: 111-166.

SÉrusiaux E., Diederich P., BRAND M. \& VAN DEN BoOM P. 1999. New or interesting lichens and lichenicolous fungi 
from Belgium and Luxembourg. VIII. Lejeunia, n.s. 162: $1-95$.

Smith C. W., Aptroot A., Coppins B. J., Fletcher A., GilBert O. L., James P. W. \& Wolseley P. A. (eds) 2009. The lichens of Great Britain and Ireland. The British Lichen Society, London.

STEIN B. 1879. Flechten. In: F. COHN (ed.), Kryptogamenflora von Schlesiens. Jahresber. Schles. Ges. Vaterl. Cult. 2(2): 1-400.

SZCZEPAŃSKA K. 2007. New lichens and lichenicolous fungi of the Polish Sudety Mountains. Polish Bot. J. 52: 165-170.
SZCZEPAŃSKA K. 2008. Anthropogenic changes of lichen biota of Śnieżnik Massif and Bialskie Mountains. Acta Botanica Silesiaca, Monographiae 4: 1-291 (in Polish with English summary).

TRIEBEL D. 1989. Lecideicole Ascomyceten. Eine Revision der obligat lichenicolen Ascomyceten auf lecideoiden Flechten. Biblioth. Lichenol. 35: 1-278.

Triebel D. \& CÁCeres M. E. S. 2004. Stigmidium. In: T. H. NASH III, B. D. RYAN, C. GRIES \& F. BugARTZ (eds), Lichen flora of the Greater Sonoran Desert Region. 2: 703-707. Lichens Unlimited, Arizona State University, Tempe.

Received 25 July 2013 